\title{
Perhatian Orang tua dalam Mendukung Keterampilan Sosial Anak selama Pandemi Covid-19
}

\author{
Lia Kusuma ${ }^{\otimes_{1}}$, Dimyati ${ }^{2}$, Harun $^{3}$ \\ Pendidikan Anak Usia Dini, Universitas Negeri Yogyakarta, Indonesia(1,3) \\ Pendidikan Ilmu Keolahragaan, Universitas Negeri Yogyakarta, Indonesia(2) \\ DOI: $\underline{10.31004 / \text { obsesi.v6i1.959 }}$
}

\begin{abstract}
Abstrak
Penelitian ini bertujuan untuk mengetahui bentuk perhatian orang tua dalam mendukung keterampilan sosial anak selama masa pandemic covid-19. Alasan mengambil penelitian ini karena dengan adanya kebijakan physical distancing menuntut sementara waktu untuk tidak berinteraksi sosial secara langsung dengan teman sebaya. Metode yang digunakan dalam penelitian ini adalah metode survey dengan jenis penelitian deskriptif kuantitatif. Instrumen pengumpulan data menggunakan angket skala perhatian orang tua dan didistribusikan secara online. Teknik pengambilan sampel menggunakan purposive sampling. Responden dalam penelitian ini berjumlah 64 orang tua yang terkumpul dari hasil penyebaran kuesioner melalui broadcast Telegram, Whatsapp, IG dan FB selama 1 minggu. Hasil penelitian didapatkan bahwa $76,19 \%$ atau 48 orang termasuk ke dalam kategori tinggi dalam memberikan perhatian pada anak selama berada di rumah. Kekhawatiran orang tua akan kurang terasahnya keterampilan sosial dapat diminimalkan dengan memberikan perhatian yang dapat dilakukan di rumah melalui pemberian kasih sayang, pengawasan, pemberian keteladanan dan mengajarkan berbuat baik kepada sesama.
\end{abstract}

Kata Kunci: perhatian orang tua ; keterampilan sosial; covid-19.

\begin{abstract}
This study aims to determine the form of parental attention in supporting children's social skills during the Covid-19 pandemic. The reason for taking this research is because the existence of the physical distancing policy requires temporarily not to have direct social interaction with peers. The method used in this research is a survey method with quantitative descriptive research. The data collection instrument used a questionnaire on the parental attention scale and was distributed online. The sampling technique used purposive sampling. Respondents in this study were 64 parents who were collected from the results of distributing questionnaires via broadcast Telegram, Whatsapp, IG and FB for 1 week. The results showed that $76.19 \%$ or 48 people were included in the high category in giving attention to children while at home. Parents' concerns about the lack of honed social skills can be minimized by giving attention that can be done at home through giving love, supervision, giving examples and teaching to do good to others.
\end{abstract}

Keywords: parental attention; social skills; covid-19.

Copyright (c) 2021 Lia Kusuma, Dimyati, Harun

$\triangle$ Corresponding author :

Email Address : lia0193pasca.2019@student.uny.ac.id (Yogyakarta, Indonesia)

Received 10 December 2020, Accepted 27 December 2020, Published 3 Juni 2021 


\section{PENDAHULUAN}

Dunia saat ini sedang dilanda krisis kesehatan yang dikejutkan dengan munculnya suatu virus yang ditemukan pertama kali di Wuhan, China pada akhir desember 2019 lalu (Zhao et al., 2020). Virus Covid-19 sendiri dikenal sebagai virus yang menyerang serta menginfeksi sistem pernapasan manusia. Hingga saat ini virus Covid-19 terus menyebar, meluas dan menginfeksi mayoritas populasi negara-negara di dunia tak terkecuali Indonesia. Terhitung hingga tanggal 4 Desember 2020 jumlah kasus Covid-19 di Indonesia sebanyak 563.680 kasus (Gugus Tugas Percepatan Penanganan COVID-19, 2020). Jumlah tersebut membuat Indonesia menempati peringkat pertama dengan kasus positif terbanyak di Asia Tenggara sekaligus juga menduduki peringkat ke-22 di dunia. Maka dari itu pemerintah mengambil langkah tegas dengan memberlakukan physical distancing hingga menerapkan Pembatasan Sosial Berskala Besar atau biasa dikenal dengan singkatan PSBB. Dengan kondisi seperti saat ini membuat seluruh lapisan masyarakat yang tadinya bisa kapanpun bekerja, belajar, maupun beribadah di luar rumah kini menjadi terbatas dengan mewajibkan setiap warganya untuk tetap tinggal, bekerja dan belajar dari rumah (Jamaluddin et al., 2020).

UNICEF (2020) melaporkan sejumlah 99\% anak-anak hingga remaja di bawah delapan belas tahun di seluruh dunia atau sekitar 2,34 miliar penduduk yang tinggal di 186 negara mengalami beberapa bentuk pembatasan gerakan yang berlaku karena adanya kasus Covid19. Bahkan tercatat 82 negara memberlakukan sistem lockdown penuh dan sebanyak $60 \%$ anak tinggal di salah satu negara yang menerapkan system tersebut (Fore, 2020). Di negara Indonesia, pemberlakuan PSBB selama kurang lebih 7 bulan terhitung mulai tanggal 4 mei 2020 serta pemberlakuan kebijakan belajar dari rumah (BDR) melalui Surat Edaran Mendikbud Nomor 36962/MPK.A/HK/2020 yang menjelaskan bahwa pembelajaran harus dilakukan secara daring menjadi salah satu upaya dalam memutus rantai penyebaran Corona Virus Desease (Covid-19) (Karnawati \& Mardhianto, 2020). Perubahan sistem pembelajaran daring memang tidak begitu berarti dan tidak mengalami kendala yang krusial pada jenjang pendidikan tinggi atau menengah atas. Akan tetapi pada tingkat anak usia dini perubahan situasi dan kondisi saat ini membuat anak menjadi bingung dan belum mengerti apa yang sedang menimpanya saat ini. Padahal penting bagi anak-anak memahami apa yang sedang terjadi saat ini untuk mencegah dampak negatif yang ditimbulkan berupa kerusakan aspek perkembangan anak (Dalton et al., 2020; Wang et al., 2020). Tak terkecuali berkitan dengan aspek perkembangan sosial yang dapat diwujudkan dengan pemberian dukungan keterampilan sosial.

Adanya pandemic covid-19 juga berdampak pada kebutuhan manusia sebagai makhluk sosial menjadi terbatasi oleh adanya kebijakan physical distancing sekaligus membuat kebutuhan bermain anak menjadi tidak terpenuhi (Wiresti, 2020). Hal ini dapat dilihat dari kondisi saat ini dimana anak yang biasanya mereka belajar dengan gembira disekolah, bertemu dan bersosialisasi dengan guru dan teman-temannya sekarang terpaksa belajar dalam kondisi yang tidak biasa yaitu belajar dari rumah dalam suasana yang sedikit mencekam akibat covid-19. Padahal anak usia pra sekolah seharusnya bebas bermain dengan teman-temannya, mengingat melalui bermain anak berkesempatan untuk mengembangkan seluruh aspek perkembangannya (Wahyuni \& Azizah, 2020). Tapi dengan adanya pandemi covid-19 membatasi anak untuk berinteraksi dengan teman sebayanya. Apabila kualitas dan kuantitas interaksi dengan teman sebayanya minim dan terbatasi maka anak akan mengalami perasaan kesepian, tertekan hingga bahkan depresi. Reaksi yang terjadi pun dapat bermacammacam yang ditimbulkan, seperti mudah tersinggung atau menarik diri (D. P. Y. Wulandari, 2020). Mengingat anak usia dini juga termasuk dalam masa yang tepat untuk mengembangkan dan meningkatkan seluruh kemampuan, potensi dan keterampilan hidup (A'yun, Prihartanti \& Chusniatun 2016; Zulfitri, 2017). Maka dari itu pada tahapan ini anak memerlukan pelayanan dan stimulasi lebih, khusus dan langsung bila dibandingkan jenjang pendidikan lain. Sebab tidak mudah bagi seorang anak untuk menghadapi situasi saat ini. 
Marinho \& Casanova (2017) mengungkapkan bahwa keterampilan sosial merupakan kemampuan individu untuk melakukan perilaku-perilaku tertentu yang memungkinkannya dalm mencapai kompetensi sosialnya. Keterampilan ini meliputi berbagai respon baik itu yang sifatnya verbal maupun nonverbal, perilaku empati, keterampilan memecahkan masalah, ekspresi perasaan positif-negatif dan mengontrol diri. Hal ini diperkuat oleh Kilic \& Aytar (2017) mengatakan bahwa individu yang dapat meningkatkan hubungan sosial dengan lingkungannya dapat diwujudkan melalui perilaku empati, berpartisipasi dalam kegiatan kelompok, saling membantu, berkomunikasi dengan orang lain, melakukan negosiasi dan mampu memecahkan masalah. Sehingga perilaku-perilaku sosial tersebut dapat menjadi dasar dalam berhubungan dengan orang lain sekaligus menjadi salah satu ciri bahwa individu tersebut memang memiliki keterampilan sosial yang positif dan baik. Sebaliknya Gumpel (dalam Sarnelle, 2018) menyatakan keterampilan sosial yang buruk dapat menyebabkan kesepian, rendahnya kompetensi sosial anak di masa mendatang, masalah kesehatan mental hingga penyalahgunaan obat-obatan. Hal ini dapat terlihat pada kondisi saat ini yang menunjukkan adanya peningkatan gangguan psikologis selama masa pandemic covid-19.

Situasi pandemic covid-19 saat ini tentunya memberi dampak terhadap kompetensi sosial anak karena anak merasa terisolasi di dalam rumah, tidak bisa bermain bebas ataupun melakukan interaksi sosial dengan teman sebayanya. Dr. Barbara Nosal Ph.D. selaku terapis keluarga di Newport Academy, AS (dalam Lindberg, 2020) mengungkapkan efek negatif yang ditimbulkan selama pandemic covid-19 bagi perkembangan sosial anak diantaranya anak akan kehilangan kesempatan untuk membangun keterampilan sosialnya, seperti kemampuan berinteraksi dengan teman sebaya, memecahkan masalah, mempelajari respons orang lain, memenuhi harapan sosial maupun berlatih untuk memiliki sikap empati. Sejalan dengan pendapat tersebut, H. Wulandari \& Purwanta (2020) yang meneliti tentang Pencapaian Perkembangan Anak Usia Dini di TK selama Pembelajaran Daring saat Pandemi Covid-19 menemukan bahwa sebesar 44 orang dari total 46 anak mengalami penurunan terkait pencapaian aspek perkembangan sosial emosi selama pandemic covid-19 terutama dalam segi perkembangan prososial. Fauziddin et al. (2021) menemukan bahwa tanpa keterlibatan dan partisipasi antara anak, guru, serta orang tua dalam pembelajaran daring tidak efektif. Lebih dari itu kondisi pandemic covid-19 juga akan berpengaruh terhadap kesehatan mental anak. Hal ini sejalan dengan pernyataan Prihantoro (dalam Azizah, 2020) bahwa apabila orang tua tidak mendukung keterampilan sosial anak, maka tidak menutup kemungkinan bagi anak mengalami gangguan psikologis, sebab mereka memiliki kerentanan tinggi terhadap hal tersebut. Sebab anak usia 2 tahun ke atas merasakan kebingungan atas apa yang dialaminya di tengah pandemic covid-19 (Prodjo, 2020).

Masa kanak-kanak awal atau biasa disebut dengan masa pra sekolah adalah masa dimana perilaku sosial mengalami peningkatan yang pesat karena bertambahnya pengalaman sosial yang didapatkan oleh anak. Erikson mengungkapkan bahwa perkembangan sosial yang pesat pada masa pra sekolah berkaitan erat dengan modalitas sosial (Sukatin et al., 2020). Modalitas sosial sendiri diperoleh anak dari pengalaman anak berhubungan dengan orang lain. Namun faktanya untuk saat ini anak tidak dapat memenuhi modalitas sosial karena kondisi yang belum memungkinkan untuk anak berinteraksi dengan teman sebaya dan lingkungan sekitar sebagai salah satu dampak adanya pandemi covid-19. Peran orang tua disini menjadi kunci penting agar keterampilan sosial anak tidak menurun. Sejalan dengan itu, Erickson \& Freud (dalam Lestari, 2018) mengemukakan bahwa melalui proses belajar baik dari orang tua, teman sebaya maupun lingkungan anak dapat memperoleh keterampilan sosialnya, karena keterampilan sosial bukanlah kemampuan yang dibawa individu sejak lahir. Untuk itulah perlu perhatian orang tua secara khusus selama pandemi covid-19 sebagai upaya dalam mendukung keterampilan sosial anak di tengah pandemi covid-19.

Zulkifli mengatakan bahwa sosialisasi keluarga dapat mempengaruhi nilai sosial anak (Bastian et al., 2020), tak terkecuali dengan nilai sosial pada anak usia 3-6 tahun. Erikson menjelaskan anak berusia 3-6 tahun berada dalam kategori Inisiatif vs Rasa Bersalah (Batra, 
2013). Dimana pada tahap ini anak mulai memiliki gagasan (inisiatif) berupa ide-ide sederhana. Namun, jika anak mengalami kegagalan pada tahap ini, maka ia akan terus merasa bersalah dan tidak mampu menampilkan dirinya sendiri. Jadi dalam hal ini orang tua harus bijak dalam merespon setiap inisiatif yang dilakukan oleh anak salah satunya dengan tidak memberikan punishment agar anak terhindar dari rasa bersalah hingga yang paling terburuk anak dapat menarik diri dari interaksi sosial. Selain itu, sosialisasi dalam keluarga guna mendukung keterampilan sosial anak berusia 3-6 tahun dapat diwujudkan melalui pemberian perhatian bagi anak, misalnya dengan mengenalkan nilai-nilai agama melalui aktivitas membaca dongeng kisah-kisah nabi. Hal ini dilakukan agar anak memiliki konsep yang kuat bahwa berbuat baik adalah bagian dari nilai-nilai agama dan kemanusiaan, dan hal ini penting guna menunjang keterampilan sosial pada anak. Suryabrata (dalam Saputri et al., 2019) mengungkapkan perhatian orang tua adalah pemusatan tenaga psikis yang tertuju pada suatu objek, atau banyak sedikit kesadaran yang menyertai suatu aktivitas yang dilakukan oleh orang tua . Aktivitas yang dimaksud ialah dalam rangka memenuhi kebutuhan dalam upaya mendukung seluruh aspek perkembangan anaknya, baik kebutuhan lahir (material) maupun kebutuhan batin (kebutuhan psikis).

Perhatian orang tua berfungsi sangat esensial dalam hal pertumbuhan sosial anak selama pandemic covid-19 (Nandwijiwa \& Aulia, 2020). Akan tetapi orang tua tidak boleh memberikan perhatian secara berlebihan atau kekurangan. Orang tua harus memberikan perhatiannya sesuai dengan kebutuhan anak dalam hal ini kebutuhan anak dalam rangka mendukung keterampilan sosial anak selama pandemic covid-19. Perlu diingat bahwa orang tua tidak boleh berlebihan dalam memberikan perhatian karena akan mengakibatkan anak stress dan merasa tertekan sebaliknya apabila perhatian orang tua yang kurang maka akan mengakibatkan anak dalam memenuhi kebutuhannya tidak sesuai dengan harapan (Mahmudi et al., 2020).

Uraian di atas menunjukkan pentingnya perhatian orang tua dalam mendukung keterampilan sosial anak selama pandemic covid-19. Penelitian ini sekaligus bertujuan untuk memberikan gambaran mengenai bentuk perhatian seperti apakah yang di terapkan oleh orang tua selama masa pandemic covid-19 guna mendukung keterampilan sosial pada anak pra sekolah.

\section{METODOLOGI}

Metode yang digunakan dalam penelitian ini ialah metode survey dengan jenis penelitian deskriptif kuantitatif (Sunardi \& Kriswanto, 2020). Metode survey dilakukan dengan cara membagikan kuesioner dalam bentuk Google Form (Permata \& Bhakti, 2020). Kemudian Google form tersebut disebarkan melalui beberapa aplikasi online seperti melalui aplikasi Facebook, Whatsapp, Telegram dan Instagram untuk memudahkan peneliti dalam mendapatkan data. Survei dilakukan mulai tanggal 25 November-2 Desember 2020 dan didapatkan 64 orang tua selaku responden. Teknik pengambilan sampel menggunakan teknik purposive sampling yaitu pemilihan sampel dengan pertimbangan tertentu (Sugiyono dalam Choirina, 2020). Pertimbangan tersebut diantaranya orang tua yang mempunyai anak berusia 3-6 tahun, karena anak pada usia tersebut masuk dalam kategori anak-anak awal atau pra sekolah (Haryanti et al., 2019), anak yang tinggal dengan orang tua hingga orang tua yang mengerti bagaimana cara penggunaan internet dan layanan google form. Adapun tujuan dari angket pada penelitian ini adalah untuk mendapatkan gambaran bagaimana bentuk perhatian orang tua dalam rangka mendukung keterampilan sosial anak selama masa pandemi covid-19 yang mana semua kegiatan, baik itu aktivitas bekerja, belajar dan beribadah hanya bisa dilakukan di rumah. Alat ukur yang digunakan untuk mengukur variabel perhatian orang tua mengadaptasi skala perhatian orang tua yang digunakan oleh peneliti sebelumnya yaitu skripsi Mahanani (2015) dengan nilai cronbach's alpha sebesar 0,887. 


\section{Tabel 1. kisi-kisi Perhatian Orang tua}

\begin{tabular}{lll}
\hline Variabel & \multicolumn{1}{c}{ Subvariabel } & \multicolumn{1}{c}{ Indikator } \\
\hline Perhatian & Perasaan Cinta Kasih & a. Perasaan cinta kepada anak \\
Orang tua & & b. Penyediaan fasilitas kebutuhan anak \\
& Pengawasan & a. Pengawasan dalam rumah \\
& & b. Pengawasan di luar rumah \\
& Pemberian Keteladanan & c. Pengawasan waktu luang \\
& a. Pembinaan mental agama \\
& Mengajarkan berbuat & b. Keteladanan berbicara \\
& baik kepada sesama & a. Saling menghormati \\
& & b. Saling membantu
\end{tabular}

Instrument angket berupa pernyataan tertutup sejumlah 30 pernyataan. Pernyataan terkait dengan indikator perasaan cinta kasih, pengawasan, pemberian keteladanan dan mengajarkan berbuat baik kepada sesama. Tentunya indikator-indikator tersebut disesuaikan dengan kondisi pandemic covid-19 yang saat ini dihadapi oleh anak. Berikut ini penjabaran instrument penelitian yang menjadi tolak ukur pemerolehan data. Untuk memberikan pendapat digunakan penilaian skala Likert yaitu Tidak Pernah, Jarang, Sering, Selalu. Skala perhatian orang tua menggunakan sejumlah item pernyataan yang terdiri dari pernyataan favorable dan unfavorable. Selanjutnya seluruh data yang terkumpul dan diperoleh selanjutnya di analisis menggunakan bantuan Microsoft Excel. Untuk lebih jelasnya mengenai alur penelitian dapat dilihat pada gambar 1 .

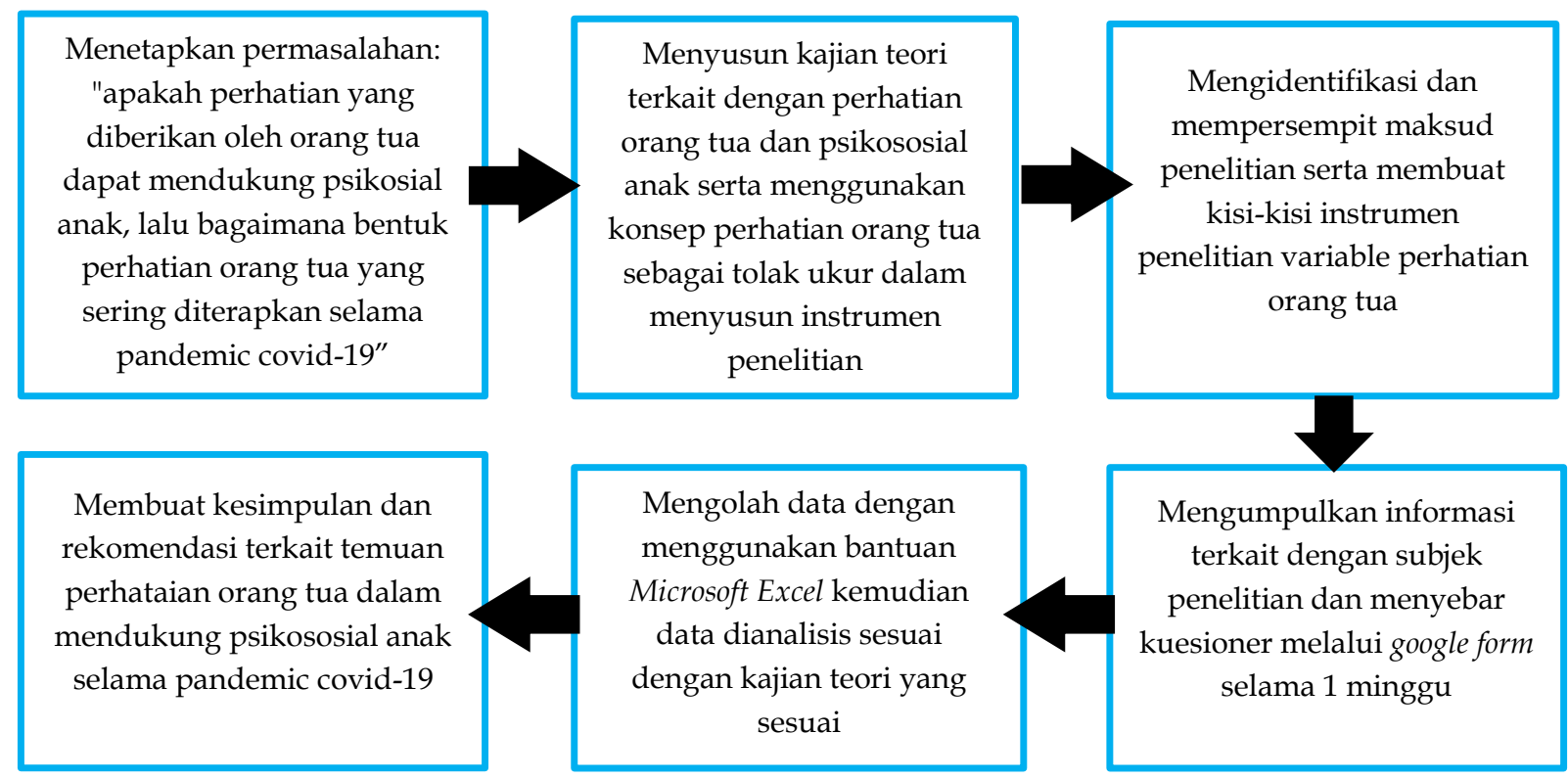

Gambar 1. Alur Penelitian Enam Tahapan (Sloane \& Seale, 2009)

\section{HASIL DAN PEMBAHASAN}

Adapun gambaran data penelitian yang akan dijabarkan dalam penelitian ini, yaitu variabel perhatian orang tua. Sub variabel perhatian orang tua terdiri dari berbagai sub variabel yang meliputi perasaan cinta kasih, pengawasan, pemberian keteladanan dan mengajarkan berbuat baik kepada sesama. Rata-rata hasil perhatian orang tua dalam mendukung keterampilan sosial anak dapat dilihat dalam Tabel 2.

Sedangkan indikator perhatian orang tua dalam penelitian ini meliputi perasaan cinta kepada anak, penyediaan fasilitas kebutuhan anak, pengawasan dalam rumah, pengawasan di luar rumah, pengawasan waktu luang, pembinaan mental agama, keteladanan berbicara, 
keteladanan dalam bersikap, saling menghormati dan saling membantu. Dari deskripsi di bawah ini terlihat gambaran beberapa item pernyataan variabel perhatian orang tua dalam mendukung keterampilan sosial anak selama masa pandemic covid-19:

Tabel 2. Rata-Rata Perhatian Orang tua dalam Mendukung Keterampilan Sosial Anak

\begin{tabular}{lcccc}
\hline \multicolumn{1}{c}{ Sub Variabel } & Selalu & Sering & Jarang & Tidak Pernah \\
\hline Perasaan Cinta Kasih & $36 \%$ & $47 \%$ & $12 \%$ & $5 \%$ \\
Pengawasan & $32 \%$ & $45 \%$ & $20 \%$ & $3 \%$ \\
Pemberian Keteladanan & $45 \%$ & $42 \%$ & $8 \%$ & $6 \%$ \\
Mengajarkan Berbuat Baik Kepada Sesama & $47 \%$ & $43 \%$ & $6 \%$ & $4 \%$ \\
\hline
\end{tabular}

\section{Perasaan Cinta Kasih}

Setiap orang tua memberikan cinta kasih sayangnya sebagai wujud perhatian orang tua . Sejalan dengan itu, Bambang Arifin (dalam Azhari et al., 2019) menyatakan hubungan cinta kasih sayang dalam sebuah keluarga tidak hanya akan membentuk ikatan persaudaraan saja melainkan dapat membentuk pula sebuah persahabatan, kebiasaan hingga memiliki persamaan terhadap pandangan nilai-nilai kehidupan, tak terkecuali nilai kehidupan sosial. Staub (dalam Negoro \& Lestari, 2019) menyatakan bahwa hubungan kasih sayang antara anak dengan orang tua akan menjadi dasar atau fundamental bagi perkembangan kecenderungan berperilaku prososial. Pendapat tersebut juga didukung oleh hasil penelitian yang dilakukan Hoffman; Sears, et al., (dalam Azhari et al., 2019) yang menunjukkan bahwa kasih sayang orang tua merupakan faktor yang penting bagi perkembangan sosial anak seperti ketentuan nilai-nilai moral, pengenalan sikap prososial dan kecenderungan untuk berperilaku prososial.

\section{Perasaan Cinta Kasih}

Bertanya dan mencari tahu perubahan yang

Mendengarkan keluh kesah dan memberikan.

Menyedikan alat permainan menarik di rumah

Menyediakan buku berisikan nilai sosem positif

Memberikan apresiasi katika anak menyelesaikan.

Menyediakan waktu untuk bermain bersama

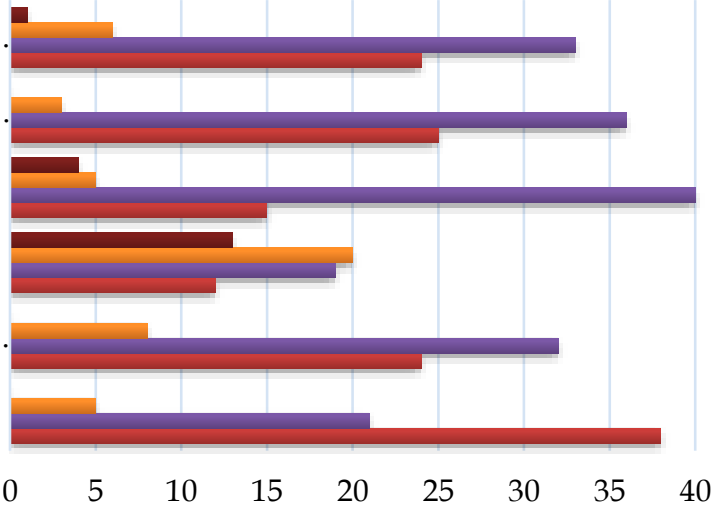

\section{Gambar 2. Grafik hasil presentase Sub Variabel Perasaan Cinta Kasih}

Gambar 2 memperlihatkan sebanyak 59\% (38 orang tua ) selalu menyediakan waktu untuk bermain bersama sebagai bentuk dari perhatian orang tua . Saat keadaan normal, orang tua dan anak bisa melakukan aktivitas bermain bersama dimana saja tanpa harus terbatasi, namun berbeda untuk saat ini mau tidak mau orang tua harus mengajak anak bermain walaupun hanya di dalam rumah. Ini semua dilakukan agar perkembangan anak selama pandemic covid-19 tidak mengalami penurunan. Hal tersebut sesuai dengan pendapat (Fakhriyani, 2018) bahwa bermain dapat mempengaruhi semua perkembangan di dalam diri anak, termasuk perkembangan sosial yang diwujudkan dengan pemberian kesempatan kepada anak untuk mengeksplor dirinya sendiri, orang lain maupun obyek yang ada di 
lingkungan sekitarnya. Hal yang sama diungkapkan oleh Tahmores (2011) bahwa dengan bermain, anak tidak hanya dapat melatih perilaku sosialnya, tetapi juga memberikan kesempatan pada anak untuk memodifikasi dan mengembangkan perilaku, khususnya pada tingkah laku sosial. Dengan begitu, anak dapat memperoleh keberanian untuk berinteraksi sosial dengan kelompok masyarakat dan belajar bagaimana menciptakan dan mengembangkan hubungan sosial dalam berbagai tahapan kehidupan serta bertanggung jawab agar diterima oleh kelompok sosialnya.

Sebagian besar anak menyukai aktivitas bermain sehingga anak akan menggunakan waktunya untuk bermain dan melalui bermain pulalah anak akan belajar untuk membina suatu hubungan dengan orang lain, bertingkah laku sesuai dengan tuntutan dan harapan masyarakat, mampu beradaptasi, dapat memahami tingkah lakunya sendiri, dan paham akan sebuah konsekuensi (Setiawan, 2017). Kegiatan bermain juga sebagai sarana untuk anak-anak mengisi kejenuhannya dan mengusir kebosanan dengan kegiatan positif selama berada di rumah. Keterampilan sosial akan berkembang baik pada anak jika orang tua mampu menjalin interaksi sosial yang baik seperti melalui permainan, serta dapat menjalin komunikasi melalui kegiatan yang bersifat kebersamaan (Syafrida, 2014). Kebersamaan ini mungkin tidak bisa dirasakan anak saat keadaan normal karena kesibukan pekerjaan orang tua yang padat.

Sebanyak 62\% (40 orang tua ) sering memfasilitasi dengan menyediakan alat permainan yang menarik bagi anak saat berada di rumah tentunya ini semua dilakukan untuk mencegah anak dari rasa kebosanan dan kejenuhan yang menderanya. Dalam bermain terdapat berbagai macam permainan, diantaranya adalah permainan tradisional dan permainan modern. Prantoro (2015) mengungkapkan bahwa ada pengaruh signifikan yang ditimbulkan dari permainan tradisional terhadap keterampilan sosial anak usia dini terutama dalam kaitannya dengan komunikasi, penerimaan teman sebaya (peer acceptence), membina hubungan kelompok dan mengatasi konflik dalam bermain. Permainan tradisional memiliki banyak nilai-nilai sosial positif, seperti: nilai-nilai kebersamaan, kejujuran, tanggung jawab, toleransi, keakraban, kreatif, mandiri solidaritas, sportivitas serta taat pada aturan. Sedangkan pada permainan modern orang tua juga dapat menstimulasi keterampilan sosial anak, misalnya pada permainan balok kayu. Saat kegiatan permainan balok kayu berlangsung, anak diberikan instrkuksi dan aturan yang berlaku, salah satu peraturan yang diterapkan yakni bergantian dalam mengambil balok kayu. Saat bermain balok kayu, anak akan lebih percaya diri hal ini dapat dilihat ketika menyampaikan dan melakukan kegiatan mengambil balok dari susunannya. Tidak hanya itu, melalui kegiatan modern anak akan mempunyai rasa saling menghargai pada temannya, hal ini dapat dilihat ketika ada teman yang sedang mengambil balok dari susunan maka anak akan memberikan masukan serta memperhatikan temannya (Karo et al., 2019)

Sebanyak 31\% (20 orang tua ) dalam kategori jarang dengan presentase yang paling tinggi yaitu menyedikan buku-buku bergambar ataupun buku dongeng yang berisikan nilainilai sosial positif misalnya nilai pentingnya kerjasama, saling tolong-menolong, dsb. Begitupun juga dengan perhatian orang tua yang masuk dalam kategori tidak pernah dengan presentase tertinggi sebanyak 20\% (13 orang tua ) yaitu dalam kaitannya memberikan fasilitas dengan menyediakan buku-buku bergambar atau mendongeng yang berisikan nilai sosial positif bagi anak. Melalui penyediaan buku bergambar yang berisikan dengan nilai-nilai sosial yang positif seperti kerjasama, empati, saling tolong menolong dan sebagainya. Diharapkan melalui penyediaan buku tersebut anak dapat membina keterampilan sosialnya sehingga akan diterima oleh teman sebaya, guru bahkan menjadi pribadi yang sukses dalam akademis. Pada dasarnya keterampilan sosial merupakan perilaku yang dapat diterima secara sosial (Takahashi et al., 2015). Adapun beberapa keterampilan sosial pada anak dapat ditunjukkan melalui adanya rasa empati, berpartisipasi dalam kelompok, kemurahan hati, menolong, berkomunikasi dengan orang lain, bernegosiasi, dan dapat memecahkan masalah (Lynch \& Simpson, 2010). Sebaliknya apabila anak tidak mau berempati, tidak mau menaati aturan, tidak menghargai orang lain, tidak mampu bekerjasama, tidak dapat mengontrol diri, tidak 
dapat menyesuaikan diri dengan orang lain akan sangat mempengaruhi pada penolakan yang terjadi di sekitar anak.

\section{Pengawasan}

Secara umum untuk melindungi anggota keluarga, peran pengawasan menjadi salah satu cara efektif untuk diterapkan. Dalam sebuah keluarga peran pengawasan ditunjukkan dengan interaksi yang terjalin antara orang tua dengan anak, yang di dalamnya berperan untuk melindungi, membesarkan dan mendisiplinkan anak (Pratiwi et al., 2018). Pengawasan wajib diberikan pada anak semata-mata agar anak dapat terkontrol dan diarahkan. Tentunya pengawasan yang dimaksud bukan berarti dengan mengawasi selama 24 jam setiap perilaku yang dilakukan oleh anak ataupun menimbulkan suatu kecurigaan yang tanpa ada dasarnya. Tetapi pengawasan yang dibangun dengan berlandaskan komunikasi dan keterbukaan. Sejalan dengan pendapat Duncan et al., (2009) bahwa peran ini berkaitan dengan dimensi pemahaman dan penerimaan untuk tidak menghakimi, serta melibatkan perhatian penuh dari berbagai atribusi dan harapan yang dibuat orang tua berkaitan dengan persepsi interaksi pengasuhan. Dalam mendukung keterampilan sosial tentunya orang tua perlu secara langsung ataupun tidak langsung untuk mengawasi dengan siapa anak bergaul dan apa yang dilakukan anak, sehingga dapat meminimalisir dampak negatif yang ditimbulkan anak.

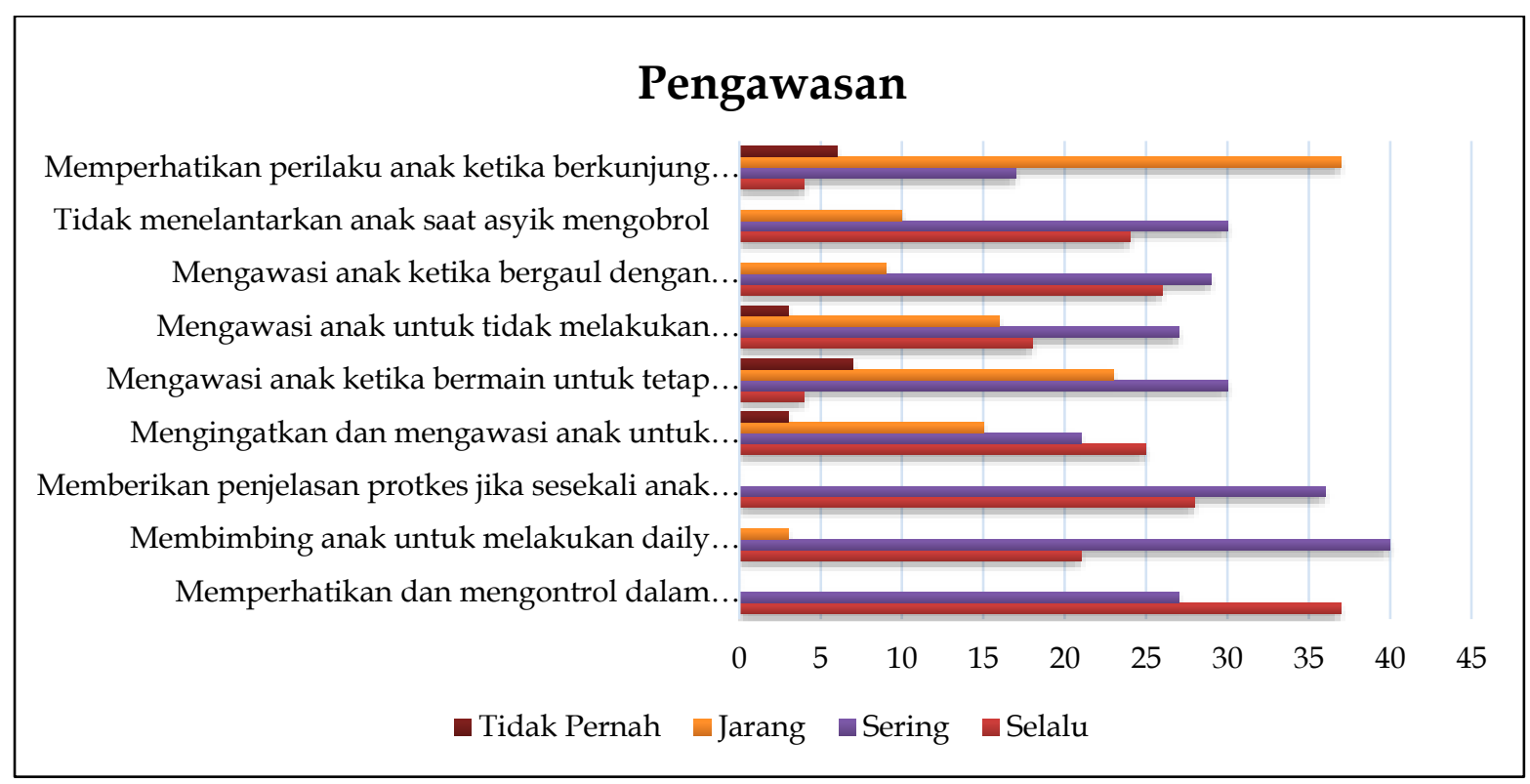

\section{Gambar 3. Grafik Hasil Presentase Sub Varibel Pengawasan}

Gambar 3 memperlihatkan pendapat orang tua dalam mengawasi anak sebagai salah satu bentuk perhatian dalam upaya mendukung keterampilan sosial anak selama pandemic covid-19. Sebanyak 58\% (37 orang tua ) selalu memperhatikan dan mengontrol anaknya dalam bermain gadget ataupun melihat telivisi ketika berada di rumah. Hal ini dikarenakan jika anak menggunakan gadget dengan frekuensi yang tinggi akan menjadikan anak sebagi pecandu gadget dimana pada fase ini anak tersebut tidak menghiraukan orang yang ada disekitarnya baik dalam lingkungan keluarga maupun masyarakat. Mukarromah (2019) mengungkapkan bahwa penggunaan gadget yang berlebihan akan memberikan dampak negatif bagi keterampilan sosial anak diantaranya anak-anak lebih banyak menirukan adeganadegan dari animasi atau adegan dalam sinetron yang mereka tonton, menjadi kurang berinteraksi dengan orang lain serta menjadi kecanduan dalam bermain gadget dan tidak ingin mengerjakan hal-hal lainnya. Selain itu, anak-anak yang sering menggunakan gadget akan menjadi pribadi yang bersikap individual dan pasif dalam berinteraksi (Damayanti et al., 2020). 
Oleh karenanya peran orang tua sebagai pengawas ialah dengan membuat kesepakatan tentang peraturan bermain gadget, kemudian bisa membuat jadwal harian, menentukan jam bermain gadget misalnya ketika harus mengerjakan tugas-tugas daring dari sekolah atau waktu santai di pagi hari ketika mereka ingin berinteraksi dengan temantemannya secara daring serta mengkontrol apa-apa saja yang diakses anak dalam gadgetnya. Apabila orang tua mendampingi, mendidik, mengajarkan dan membuat peraturan dalam menggunakan gawai pada anak, maka perkembangan sosial anak akan berkembang dengan baik (Annisa et al., 2019). Begitupun juga dengan pengawasan orang tua saat anak menonton televisi yang dinilai sangatlah penting untuk dilakukan. Hal ini bertujuan untuk meminimalisir tayangan-tayangan negatif yang dapat ditiru oleh anak. Dengan adanya pengawasan dari orang tua saat menonton televisi orang tua dapat mengarahkan perilaku yang seharusnya dilakukan anak sekaligus sebagai penerjemah bagi anak untuk mengetahui mana perilaku yang baik dan mana perilaku yang salah, mana adegan yang patut untuk ditiru dan mana adegan yang tidak patut untuk ditiru (Astarini et al., 2018).

Sebanyak 62\% (40 orang tua ) sering mengajak serta membimbing anak untuk melakukan daily routine secara bersama-sama. Berbagai aktivitas dapat diciptakan untuk mengisi kegiatan di rumah bersama anak misalnya mengajak anak untuk memasak, menyiram tanaman, mencuci kendaraan, berkebun dan sebagainya. Di samping itu, momen melakukan aktivitas harian secara bersama-sama mungkin selama ini sudah jarang dilakukan karena kesibukan orang tua . Tentunya aktivitas ini dapat memberi kesempatan yang baik bagi hubungan antara orang tua dengan anak karena dapat membangun dan mempererat ikatan (bonding). Mengawasi dan membimbing anak dalam melakukan pekerjaan rumah tangga dapat melatih tanggung jawab pada anak serta mengisi waktu luangnya dibandingkan saat kondisi normal bersekolah (Wardhani, 2020). Dimasa pandemic covid-19 saat ini, terdapat beberapa cara bagi para orang tua untuk dapat membantu proses pengasuhan yang positif salah satunya ialah dengan menyediakan waktu yang berkualitas saat bersama anak misalnya melibatkan anak untuk melakukan aktivitas pekerjaan rumah (UNICEF, 2020). Selain itu Hainstock (dalam Fajarwati, 2015) juga berpendapat melalui latihan keterampilan hidup dengan melibatkan dan mengijinkan anak-anak untuk melakukan aktivitas sehari-hari akan membuat anak menjadi pribadi yang dapat beradaptasi dan menunjukkan dirinya dalam kehidupan sosial.

Sebanyak 58\% (37 orang tua ) dalam kategori jarang dengan presentase yang paling tinggi yaitu memperhatikan perilaku anak saat sekali-kali orang tua mengajak anak berkunjung ke rumah saudara. Memperhatikan perilaku anak saat berkunjung ke rumah saudara adalah salah satu upaya orang tua untuk mendukung keterampilan sosial anak. Sebab yang dimaksud dengan keterampilan sosial adalah perilaku yang mendorong suatu interaksi positif dengan orang lain dan lingkungan sekitarnya (Lynch \& Simpson, 2010), termasuk pada lingkungan keluarga besar. Hubungan anak dengan kakek-neneknya, pamanbibinya, sepupu dsb, orang tua perlu memperhatikan perilaku anaknya apakah dia dapat berbagi dengan sepupunya, apakah anak dapat menunjukkan sikap sopan santun, dan yang lainnya.

Sebanyak $11 \%$ (7 orang tua ) tidak pernah mengawasi anak ketika bermain untuk tetap menjaga jarak hal ini dapat dilihat dengan grafik gambar 3 yang menunjukkan aktivitas tersebut masuk dalam kategori tidak pernah dengan persentase yang paling tinggi. Keterampilan sosial anak diperoleh terutama melalui kesempatan bertemu dengan temanteman melakukan kegiatan bermain. Sebab melalui bermain akan memberikan kesempatan kepada anak-anak untuk mempraktikkan peran sosial yang berbeda dan mempelajari aturan sosial (Stagnitti, 2004; Bodrova \& Leong, 2015). Namun mengingat ditengah-tengah masa covid-19 seperti ini, sangat penting bagi orang tua untuk mengawasi anak bermain di luar salah satunya dengan menjaga jarak. Hal ini sesuai dengan himbauan pemerintah yang menekankan pentingnya menjaga jarak untuk mencegah penularan Covid-19 (Kandari \& Ohorella, 2020). 


\section{Pemberian Keteladanan}

Pemberian keteadanan termasuk fasilitas yang terorganisir sebagai bentuk perhatian orang tua . Anak selalu memperhatikan dan meniru apa yang orang tua lakukan, bagaimana orang tua memperlakukan orang lain dan bagaimana orang tua menangani perasaannya sendiri. Hal yang sama juga dikemukakan oleh Rakhmawati (2015) yang menyatakan bahwa anak akan memperhatikan kebiasaan, pergaulan orang tua hingga aktivitas sehari-hari yang dilakukan orang tua baik itu yang bersifat positif maupun negatif kemudian anak akan meniru perilaku orang tua nya karena anak melihat hal tersebut. Maka dari itu dalam hal ini orang tua dirasa tidak perlu banyak menentukan aturan perilaku dalam keluarga, alangkah lebih baiknya jika orang tua meneladankan suatu nilai yang jelas, seperti memberi contoh untuk saling tolong menolong, bekerja sama, dsb serta mendorong anak-anak untuk mencotoh perilaku positif yang mencerminkan nilai-nilai tersebut (Umayah, 2017). Selanjutnya, teori pembelajaran sosial Bandura (dalam Connolly, 2017) telah menunjukkan bahwa pembelajaran sosial anak-anak sangat dipengaruhi oleh peniruan, penguatan dan permodelan.

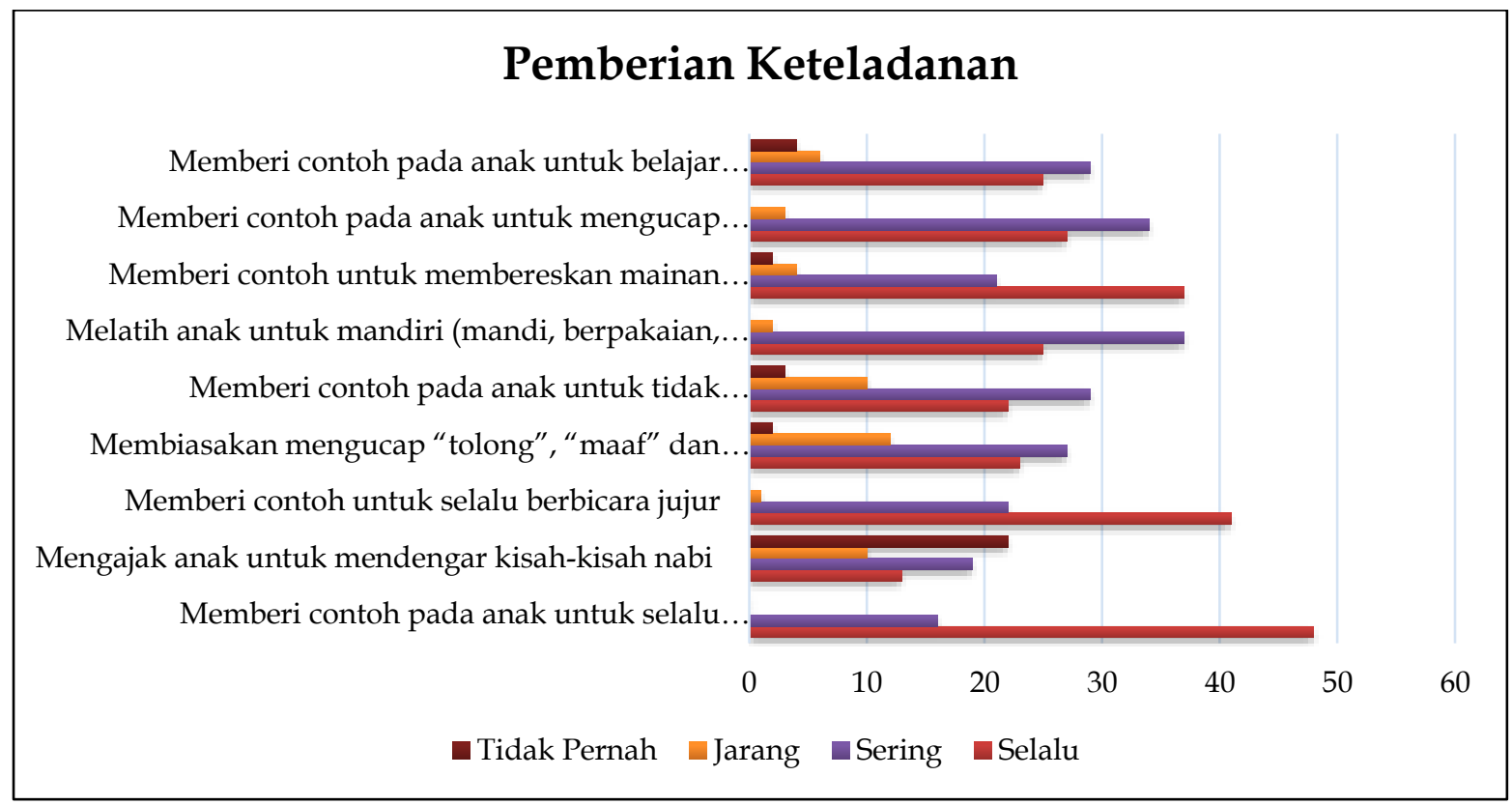

\section{Gambar 4. Grafik Hasil Presentase Sub Varibel Pemberian Keteladanan}

Gambar 4 memperlihatkan pendapat orang tua dalam memberikan keteladanan kepada anak sebagai salah satu dalam upaya mendukung keterampilan sosial anak selama pandemic covid-19. Sebanyak 75\% (48 orang tua ) selalu memberi contoh dan mengajak anak untuk selalu beribadah dan berdoa selama berada di rumah. Rumah adalah pengaturan kehidupan yang penting dalam keberhasilan untuk mengembangkan hubungan sosial anak, dan keberhasilan tersebut dapat diraih dengan banyak cara yang bisa dilakukan (Rachman \& Cahyani, 2019). Mengingat pengembangan keterampilan sosial awalnya dimulai dari rumah, maka orang tua dapat melakukan tiga hal yang membantu anak dalam mengembangkan keterampilan sosial melalui interaksi face to face, bermain bersama, dan mengajari anak memenuhi keterampilan hidupnya (dalam Rachman \& Cahyani, 2019). Dalam rangka mendukung anak untuk mempelajari keterampilan hidup (life skill) maka orang tua dapat menyadarkan anak sebagai mahluk Tuhan, harus mulai dan sanggup melakukan tindakan seperti berdoa atau sembahyang. Karena Keterampilan hidup (life skills) dimulai dengan mengajari anak bagaimana sikap bersyukur dan berdoa sebagai salah satu poin dari keterampilan spiritual semata-mata untuk memperoleh keridhoan Allah SWT (Ermayani, 2015). 
DOI: 10.31004/obsesi.v6i1.959

Sebanyak 58\% (37 orang tua ) sering melatih anak untuk mandiri misalnya mandi, berpakaian, dan makan sendiri. Hal ini dilakukan oleh orang tua dengan tujuan agar keterampilan sosial anak tidak menurun saat berada di rumah saja. Meskipun mungkin memerlukan waktu yang lebih lama dalam menerapkan kemandirian pada anak, namun hal ini dapat dimanfaatkan untuk memberikan kesempatan aktivitas bantu diri sekaligus mengisi waktu luang selama berada di dalam rumah. Aktivitas seperti mandi sendiri, makan sendiri, toilet training dimana sebelumnya anak sama sekali belum dapat melakukannya. Mulai saat ini orang tua bisa melatih dan memberi role model bagi anak secara bertahap mulai dari yang sederhana hingga menuju kegiatan yang kompleks dalam hal memenuhi kemampuan bantu diri. Kemandirian pada anak usia 4-5 tahun ini lebih mengarah pada kemampuan bantu diri anak secara langsung, yaitu tanpa melalui bantuan orang lain.

Sebanyak 19\% (12 orang tua ) masuk dalam kategori jarang dengan persentase tertinggi yaitu pada aktivitas memberi contoh dan membiasakan anak untuk mengucapkan kata "tolong", "maaf" dan "terimakasih" saat berada di rumah. Tanpa disadari, memberi contoh mengucap tiga kata ajaib tersebut menjadi wujud pemberian pengalaman oleh orang tua kepada anaknya demi menjalin komunikasi yang baik dengan orang lain. Artinya, untuk menjalin interaksi sosial yang ke arah yang lebih positif, maka orang tua perlu membiasakan dengan memberikan perlakuan dan perkataan sopan agar menjadi contoh yang baik bagi anak. Apabila anak dapat menjalin interaksi sosial yang positif dengan menunjukkan perilaku yang baik terhadap lingkungannya anak akan merasa diterima, sebaliknya jika perilaku itu tidak baik akan diberikan punishment oleh lingkungan (Cartledge, G., \& Milburn, J. F. dalam Suud, 2017). Hal yang sama dikemukakan oleh Gresham \& Reschly (1987) bahwa keterampilan sosial dapat diidentifikasi salah satunya menunjukkan ciri memiliki keterampilan dalam berkomunikasi yang dapat diwujudkan dengan pemberian umpan balik, perhatian terhadap lawan bicara, dan menjadi pendengar responsif. Keterampilanketerampilan di atas sangat diperlukan ini diperlukan untuk menjalin suatu hubungan sosial kearah yang lebih baik.

Sebanyak 34\% (22 orang tua ) termasuk dalam kategori tidak pernah yang paling tinggi terdapat pada aktivitas mengajak anak untuk mendengarkan kisah-kisah nabi, padahal aktivitas ini dilakukan orang tua agar keterampilan sosial anak tidak menurun sekaligus kesehatan mental anak menjadi lebih baik sehingga nantinya anak dapat bersosialisasi dengan baik oleh teman sebayanya di lingkungan sekitar. Melalui kisah-kisah nabi yang dibacakan, anak dapat memetik suatu nilai (value) berkaitan dengan program stimulasi yang bisa diberikan kepada anak Usia dini untuk mengembangkan keterampilan sosialnya antara lain melalui kemampuan anak mengenal dirinya, mengenal emosinya, memiliki empati, memiliki rasa simpati, meu berbagi, senang bernegosiasi, saling tolong-menolong, bekerjasama dan siap untuk bersaing (Hasanah, 2019).

\section{Mengajarkan Berbuat Baik Kepada Sesama}

Orang tua dapat mengajarkan nilai-nilai positif melalui kegiatan yang menyenangkan dan dirasa tidak membuat anak menjadi cepat bosan. Dengan adanya pendidikan tentang keterampilan sosial yang diajarkan oleh orang tua , sehingga nantinya anak mampu menerapkan apa yang sudah anak dapat mengenai keterampilan sosial seperti bersikap ramah, saling berbagi, tolong menolong, membantu orang lain yang sedang sakit terkena covid-19 dengan mendoakannya dan memiliki sikap peduli. Dengan mengajarkan keterampilan sosial yang dilakukan oleh orang tua , orang tua berharap agar anak memiliki kepribadian yang baik, saling membantu antar sesama, dan tidak terjerumus ke hal yang negatif dalam kehidupan sosialnya. Hal ini sesuai dengan pernyataan Khusniyah (2018) bahwa keterampilan sosial dapat dikembangkan salah satunya melalui proses pembelajaran dengan lingkungan orang tua guna mengoptimalkan perannya saat berinteraksi sosial. 


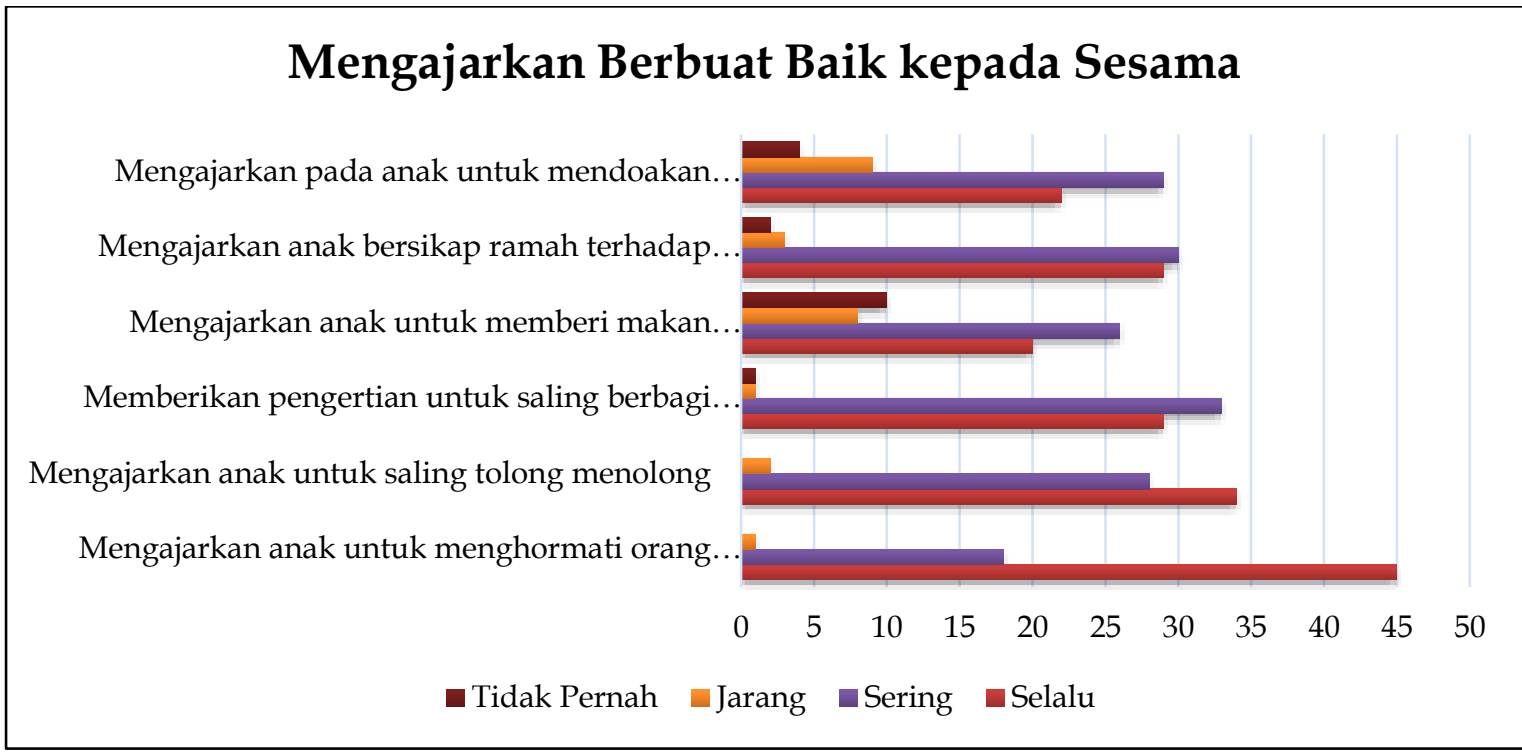

\section{Gambar 5. Grafik Hasil Presentase Sub Varibel Mengajarkan Berbuat Baik kepada Sesama}

Gambar 5 memperlihatkan pendapat orang tua dalam mengajarkan berbuat baik kepada sesama sebagai salah satu dalam upaya mendukung keterampilan sosial anak selama pandemic covid-19. Sebanyak 59\% (45 orang tua ) selalu mengajarkan anak untuk menghormati orang yang lebih dewasa sebagai upaya menjunjung tinggi nilai-nilai sopan santun sekaligus melestarikan budaya leluhur nenek moyang Indonesia. Meskipun anak saat ini berada di rumah saja, namun bukan menjadi alasan untuk tidak menerapkan sopan santun pada anak. Hal sederhana seperti mengajarkan anak bagaimana saat berbicara dengan orang yang lebih serta harus menghindari nada bicara yang tinggi atau bahkan teriak-teriak merupakan bentuk agar sikap sopan santun dapat terjaga. Hal ini penting dilakukan karena keterampilan sosial anak usia dini dapat diukur salah satunya dengan bagaimana anak memperlakukan orang yang lebih dewasa dengan sopan santun agar diterima dalam lingkungan sosialnya (P. Lestari, 2018). Hal yang sama juga dikemukakan oleh Pujiningtyas (2018) bahwa perkembangan sikap sosial yang baik dapat dilihat salah satunya apakah anak akan mampu menghormati orang lain atau orang yang lebih tua darinya.

Sebanyak 31\% (33 orang tua ) sering mengajarkan dan memberikan pengertian kepada anak untuk saling berbagi dengan orang lain. Dalam konteks ini, anak tidak harus selalu memberi dalam bentuk barang maupun uang melainkan bisa berbentuk jasa atau kasih sayang. Anak dituntut untuk merasakan kebersamaan dengan berbagi apa yang ia miliki saat ini. Dengan berbagi telah mengajarkan pada anak untuk tidak mementingkan dirinya sendiri, bisa menghargai milik dirinya maupun orang lain, juga menimbulkan sifat pemurah (Hasanah, 2019). Dalam kehidupan sosialnya anak akan mulai berinteraksi dengan anak lain yang seumuran. Kemudian mereka dihadapkan pada harapan dan tututan sosial. Untuk itu, anak mulai belajar agar diterima oleh kelompoknya dengan menjalin hubungan sosial yang akrab seperti berbagi alat permainan serta bermain dengan baik bersama temannya.

Sebanyak ( 9 orang tua ) dalam kategori jarang dengan presentase yang paling tinggi yaitu mengajarkan pada anak untuk mendoakan orang lain yang terkena covid-19. Mengajarkan anak untuk mendoakan orang lain yang terkena musibah juga termasuk dalam keterampilan sosial. Karena dengan mendoakan orang lain itu artinya anak memiliki sikap empati dan simpati sekaligus memiliki sikap kepedulian yang tinggi. Empati sendiri diartikan sebagai sikap perhatian kepada orang lain sekaligus menjadi dimensi yang berkaitan dengan perasaan dan sikap seseorang guna mendukung keterampilan sosialnya (Rachman \& Cahyani, 2019). Berbeda dengan empati, Hasanah (2019) mendefinisikan simpati sebagai bentuk perasaan dan emosi karena merasa iba serta ingin melakukan tinakan untuk mebantunya. Jadi dengan kata lain jika anak memiliki rasa simpati, ia akan dapat menghayati 
perasaan orang lain, tidak semena-mena pada orang lain otomatis anak akan memiliki kepekaan sosial yang tinggi sehingga akan memunculkan sikap pemurah. Sedangkan kepedulian yaitu rasa ingin membantu terhadap orang yang sedang membutuhkan bantuan (Nuraida \& Milyartini, 2016). Kegiatan mendoakan orang lain yang terkena musibah seperti terkena virus covid-19, akan memberikan kesadaran pada anak untuk peka terhadap perasaan orang lain dengan membayangkan dirinya berada di posisi tersebut.

Terakhir, sebanyak 10 orang tua masuk dalam kategori tidak pernah dengan presentase tertinggi yaitu dalam kaitannya mengajarkan anak untuk memberi makan hewan peliharaan ataupun bila tidak memiliki hewan peliharaan, juga dapat memberi makan hewan yang ada di sekitar rumah. Mengajari anak untuk berbagi tidak hanya pada temannya saja atau manusia saja namun juga berbagi dengan binatang termasuk ke dalam upaya mendukung keterampilan sosial yang sangat dibutuhkan anak, karena dengan berbagi akan mengajarkan anak untuk tidak bersikap acuh tak acuh atau bersikap anti sosial dengan cara mengabaikan. Jika hal ini tidak dapat diantisipasi, maka akan menyebabkan tumbuh sikap egois dan menang sendiri di dalam diri anak. Tujuan dari sikap berbagi sendiri ialah menanamkan sifat pemurah di diri anak, mengajarkan untuk tidak egois atau mementingkan diri sendiri dan bisa menghargai milik dirinya maupun hak orang lain (Hasanah, 2019). Mengapa dalam kaitannya mengajari anak berbagi makanan dengan hewan peliharaan termasuk dalam kategori tidak pernah tertinggi pada sub variabel mengajarkan berbuat baik kepada sesama? Mungkin karena beberapa alasan diantaranya anak tidak memiliki hewan peliharaan, jarang main keluar selama masa pendemi covid-19 atau bahkan takut tertular covid-19 melalui interaksi yang dilakukan anak dengan hewan yang ada di sekitar rumah.

Adapun penyajian hasil dalam penelitian ini berdasarkan pada data-data yang diperoleh dari penelitian yang telah dilakukan. Skala yang digunakan adalah skala Likert dengan tingkat jawaban skor 1 sampai dengan 4, jumlah total pernyataan sebanyak 30 item. Deskripsi data yang disajikan meliputi data secara umum yang antara lain adalah skor minimal, skor maksimal, mean, dan standar deviasi. Angket perhatian orang tua terdiri dari 30 item, setiap item diberi skor 1-4. Diperoleh skor tertinggi yaitu $30 \times 4=120$ dan skor terendah $30 \times 1=30$ dengan rentang skor $120-30=90$. Dengan demikian setiap satuan deviasi standarnya bernilai $\sigma=90 / 6=15$. Mean teoritik $(\mu)$ sebesar 150/2 $=75$. Hasil perhitungan data dapat dilihat pada rumusan tabel 3 .

Tabel 3. Deskripsi Data Perhatian Orang tua

\begin{tabular}{cclc}
\hline Variabel & Jumlah Item & Statistik & Skor \\
\hline Perhatian Orang tua & 30 item & Skor Minimum & 30 \\
& & Skor Maksimum & 120 \\
& & Mean & 75 \\
& & SD & 15 \\
\hline
\end{tabular}

Berdasarkan data pada tabel 2, dapat diketahui bahwa skor minimum ideal untuk variabel perhatian orang tua sebesar 30 dan skor maksimum ideal sebesar 120. Skor rata-rata yang didapatkan pada variabel perhatian orang tua sebesar 75 sedangkan standar deviasinya sebesar 15, sehingga dapat diperoleh batasan skor kategorisasi perhatian orang tua yang tinggi berada pada kisaran skor $\geq 90$, batasan skor kategorisasi perhatian orang tua yang sedang berada pada kisaran skor 60 sampai 90, dan kategori perhatian orang tua rendah pada kisaran skor $<60$. Adapun distribusi frekuensi yang diperoleh dari perhitungan kategori dapat dilihat pada tabel 3 beserta gambar 6 yang menunjukkan sebaran data pada masing masing kategori.

Berdasarkan data pada tabel 3 dan gambar 11, maka dapat terlihat bahwa dari 64 orang tua selaku responden dalam penelitian ini menunjukkan sebanyak $0 \%$ ( 0 orang tua ) memiliki tingkat perhatian orang tua dalam kategori rendah, $13,81 \%$ orang (15 orang tua ) memiliki tingkat perhatian orang tua dalam kategori sedang, dan 76,19\% (48 orang tua ) yang memiliki 
tingkat perhatian orang tua dalam kategori tinggi. Dari hasil tersebut dapat disimpulkan bahwa tingkat perhatian orang tua untuk mendukung keterampilan sosial anak selama pandemic covid-19 termasuk ke dalam kategori tinggi dengan skor mencapai 76,19\%.

Tabel 4. Distribusi Frekuensi Kategorisasi Perhatian Orang tua

\begin{tabular}{|c|c|c|c|c|}
\hline No. & Kategori & Kriteria & Frekuensi & Presentase \\
\hline 1 & Rendah & $X<60$ & 0 orang & $0 \%$ \\
\hline 2 & Sedang & $60 \leq X<90$ & 15 orang & $23,81 \%$ \\
\hline 3 & Tinggi & $90 \leq X$ & 48 orang & $76,19 \%$ \\
\hline \multicolumn{3}{|c|}{ Total } & 63 orang & $100 \%$ \\
\hline
\end{tabular}

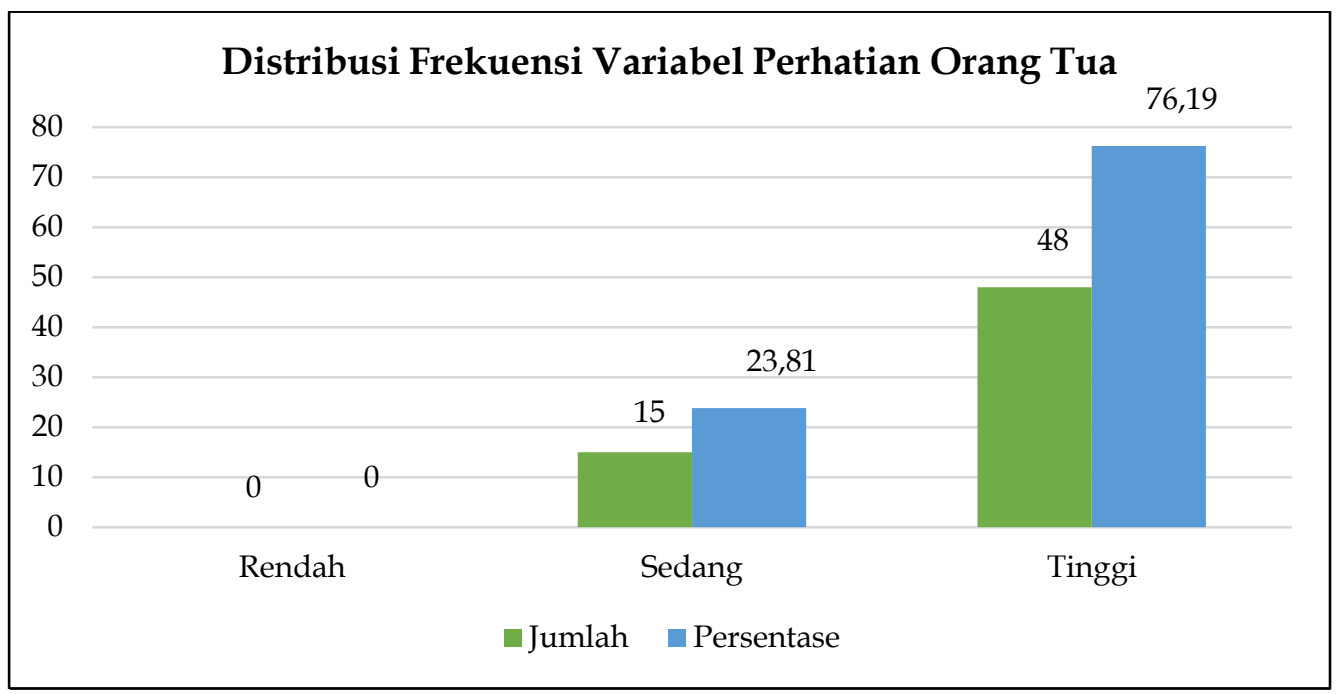

Gambar 6. Grafik Distribusi Frekuensi Variabel Perhatian Orang tua

Pada dasarnya, perhatian orang tua sangat diperlukan untuk mendukung keterampilan sosial anak selama pandemic covid-19 saat ini. Perhatian orang tua berfungsi sangat esensial dalam hal pertumbuhan sosial anak selama pandemi covid-19 (Nandwijiwa \& Aulia, 2020). Sejalan dengan hal tersebut, Ericson dan Freud (dalam Suud, 2017) mengemukakan bahwa keterampilan sosial dapat diperoleh anak melalui proses belajar dengan lingkungan terdekat anak mulai dari orang tua, teman sebaya hingga lingkungan sekitar anak bukan kemampuan yang dibawa sejak lahir. Melihat situasi dan kondisi saat ini dengan adanya pandemic covid-19 serta diberlakukannya kebijakan PSBB, dimana aktivitas anak hanya dilakukan dirumah saja sehingga interaksi sosial lebih dominan dengan orang tua . Menjadi figure orang tua bukanlah hal yang mudah, mengingat orang tua merupakan awal tempat proses sosialisasi bagi anak-anaknya sekaligus tempat anak memperoleh pemenuhan kebutuhan hidupnya baik secara fisik berupa penyediaan sarana prasarana ataupun secara psikis melalui kasih sayang dalam bentuk perhatian orang tua .

Gunarsa (dalam Pahenra et al., 2018) mengatakan bahwa dalam berinteraksi dengan anak, tanpa disadari orang tua tidak sengaja menunjukkan sikap tertentu. Dengan begitu, anak secara sadar melihat dan menerima sikap, reaksi, kebiasaan dan tingkah laku orang tua nya, sehingga akhirnya menjadi suatu pola kepribadian dalam diri anak. Karena pada dasarnya sejak awal kelahiran sudah terjadi adanya proses sosialisasi antara orang tua dengan anak sehingga dengan berjalannya waktu proses sosialisasi tersebut mempengaruhi keterampilan sosial anak. Fitri Nurhayati (dalam Mahanani, 2015) menyatakan dukungan yang bisa diberikan orang tua terhadap keterampilan sosial anaknya dapat berupa perhatian terhadap pemenuhan kebutuhan psikis yang meliputi memberi pengawasan, memberi penghargaan dan hukuman, memberi contoh, dan membantu kesulitannya. Pada dasarnya 
dukungan orang tua juga dapat terlihat apabila anak dibekali dengan keterampilan kontrol diri dengan cara pemberian Teknik bimbingan yang sifatnya positif, seperti modelling, dorongan berperilaku baik, dan menentukan batasan-batasan aturan sosial secara jelas.

Hasil penelitian Rubin et al., (2008) dan Coplan et al., (2013) mengatakan dalam penelitiannya sebanyak 367 anak-anak mengalami kesulitan dalam sosial emosionalnya karena minimnya perlakuan yang diberikan oleh keluarga. Dengan dasar hasil penelitian tersebut dapat ditarik kesimpulan bahwa keterampilan sosial penting untuk didukung sedini mungkin, karena akan memberi pengaruh untuk masa depan anak. Sejalan dengan itu Gouley et al. (2008) dalam penelitiannya menemukan bahwa anak-anak yang supel, kooperatif dan ramah lebih berhasil dalam konteks sekolah, sosial maupun dari segi akademis sedangkan anak-anak yang kurang keterampilan sosial biasanya menunjukkan perilaku bermasalah (Langeveld et al., 2012). Untuk itu hal ini menjadi catatan penting untuk diperhatikan oleh orang tua . Jika orang tua memperhatikan anaknya, maka anak bisa menjalin hubungan baik dengan orang lain, seperti bertingkah laku sesuai dengan nilai dan aturan sosial, karena sebelumnya sudah diterapkan dalam keluarga sehingga menjadi sebuah kebiasaan.

Dari uraian di atas, jelas bahwa perhatian orang tua dalam mendukung keterampilan sosial anak usia dini sangat berperan penting. Faktor keterlibatan orang tua dalam perkembangan anak dapat memicu keterampilan sosialnya, sehingga keterampilan sosial khususnya bagi anak usia 3 hingga 6 tahun juga akan semakin meningkat. Namun sebaliknya, jika orang tua tidak peduli sama sekali maka anak akan sulit atau tidak akan berkembang keterampilan sosialnya. Selain itu, jika anak memiliki keterampilan sosial yang baik tentunya akan membantu anak dalam berteman serta menjadi bekal kehidupan selanjutnya untuk menjalani hidup didalam lingkungan sekitar.

\section{SIMPULAN}

Perhatian orang tua dalam mendukung keterampilan sosial anak menunjukkan persentase yang tinggi, itu artinya orang tua tahu betul akan perannya dalam menstimulasi keterampilan sosial anak selama masa pandemic covid-19. Hal ini dilakukan orang tua untuk mencegah penurunan kemampuan bersosialisasi anak hingga gangguan kesehatan mental bagi anak selama pandemic covid-19. Untuk peneliti selanjutnya yang ingin melakukan penelitian sejenis, agar menambah responden yang digunakan guna memperoleh hasil yang lebih akurat. Selain itu diharapkan pula dapat meneliti sub variabel pengaruh orang tua lainnya yang tidak disertakan dalam penelitian ini, sehingga nantinya hasil yang didapatkan bisa diperbandingkan.

\section{UCAPAN TERIMA KASIH}

Terimakasih saya ucapkan kepada teman-teman, responden dan semua pihak yang sudah membantu mulai dari menyebar link kuesioner, meluangkan waktunya untuk mengisi kuesioner hingga pembuatan artikel jurnal penelitian dapat berjalan dengan baik dan lancar.

\section{DAFTAR PUSTAKA}

A'yun, Q., Prihartanti, N., \& Chusniatun. (2015). Peran Orangtua dalam Pendidikan Anak Usia Dini (Studi Kasus pada Keluarga Muslim Pelaksana Homeschooling). Jurnal Indigenous, $13(2)$, 33-40. http://journals.ums.ac.id/index.php/indigenous/article/view/2601

Annisa, A., Marlina, S., \& Zulminiati, Z. (2019). Hubungan Persepsi Orang Tua Tentang Dampak Smartphone Terhadap Perkembangan Sosial Pada Anak Di Kelompok Bermain Gugus I Kecamatan Nanggalo Kota Padang. Jurnal Ilmiah POTENSIA, 4(1), 59-66. https:// doi.org/10.33369/jip.4.1.59-66 
Astarini, N., Hamid, S. I., \& Rustini, T. (2018). Studi Dampak Tavangan Televisi Terhadap Perkembangan Perilaku Sosial Anak. Cakrawala Dini: Jurnal Pendidikan Anak Usia Dini, 8(1). https://doi.org/10.17509/cd.v8i1.10554

Azhari, T. D., Bahari, Y., \& Ulfah, M. (2019). Pelaksanaan Fungsi Keluarga dalam Mendidik Anak Pada Keluarga Broken Home di RW 04 Kelurahan Tanjung Hulu. Jurnal Pendidikan Dan Pembelajaran Khatulistiwa, 8(3), 1-8.

Azizah, N. (2020). Ahli Sebut Pandemi Berdampak Pada Psikologis Anak. Republika.Co.Id.

Bastian, R., Syur'aini, \& Ismaniar. (2020). Pengaruh Sosialisasi dalam Keluarga Terhadap Perkembangan Sosial Anak Usia Dini di Masyarakat Desa Koto Lamo Sumatera Barat. Indonesian Journal Of Adult and Community Education, 2(1), 16-25.

Batra, S. (2013). The Psychosocial Development of Children: Implications for Education and Society - Erik Erikson in Context. Contemporary Education Dialogue, 10(2), 249-278. https:// doi.org/10.1177/0973184913485014

Bodrova, E., \& Leong, D. J. (2015). Vygotskian and Post-Vygotskian Views on Children's Play. American Journal of Play, 7(3), 371-388.

Choirina, V. N. (2020). Hubungan kebiasaan orang tua mendongeng dengan buku dan kemampuan membaca permulaan pada anak usia kelompok B. Jurnal Pendidikan Anak, 9(1), 63-69. https:// doi.org/10.21831/jpa.v9i1.31354

Connolly, G. J. (2017). Applying Social Cognitive Theory in Coaching Athletes: The Power of $\begin{array}{llll}\text { Positive Role } \quad \text { Models. 23-29. } & \text { 30(3), }\end{array}$ https:// doi.org/10.1080/08924562.2017.1297750

Coplan, R. J., Rose-Krasnor, L., Weeks, M., Kingsbury, A., Kingsbury, M., \& Bullock, A. (2013). Alone is a crowd: Social motivations, social withdrawal, and socioemotional functioning in later childhood. Developmental Psychology, 49(5), 861-875. https://doi.org/10.1037/a0028861

Dalton, L., Rapa, E., \& Stein, A. (2020). Protecting the psychological health of children through effective communication about COVID-19. The Lancet Child and Adolescent Health, 4(5), 346-347. https:// doi.org/10.1016/S2352-4642(20)30097-3

Damayanti, E., Ahmad, A., \& Bara, A. (2020). Dampak Negatif Penggunaan Gadget Berdasarkan Aspek Perkembangan Anak Di Sorowako. Martabat: Jurnal Perempuan Dan Anak, 4(1), 1-22. https:// doi.org/10.21274/martabat.2020.4.1.1-22

Ermayani, T. (2015). Pembentukan Karakter Remaja Melalui Keterampilan Hidup. Jurnal $\begin{array}{lll}\text { Pendidikan } \quad \text { Karakter, 2, } & \text { 127-141. }\end{array}$ https:// doi.org/https:// doi.org/10.21831/jpk.v0i2.8618

Fajarwati, A. (2015). Penerapan Latihan Kehidupan Praktis Anak Usia 3- 4 Tahun. Jurnal Ilmiah VISI PPTK PAUDNI, 10(1), 21-28.

Fakhriyani, D. V. (2018). Pengembangan Keterampilan Sosial Anak Usia Dini Melalui Permainan Tradisional Madura. Jurnal PG-PAUD Trunojoyo : Jurnal Pendidikan Dan Pembelajaran Anak Usia Dini, 39-44. https://doi.org/10.21107/pgpaudtrunojoyo.v5i1.3685

Fauziddin, M., Mayasari, D., \& Rizki, L. M. (2021). Effective Learning for Early Childhood during Global Pandemic. Al-Ishlah: Jurnal Pendidikan, 13(1).

Fore, H. (2020). Jangan biarkan anak-anak menjadi korban tersembunyi pandemi COVID-19.

Gouley, K. K., Brotman, L. M., Huang, K. Y., \& Shrout, P. E. (2008). Construct validation of the social competence scale in preschool-age children. Social Development, 17(2), 380-398. https://doi.org/10.1111/j.1467-9507.2007.00430.x

Gresham, F. M., \& Reschly, D. J. (1987). Dimensions of social competence: Method factors in the assessment of adaptive behavior, social skills, and peer acceptance. Journal of School Psychology, 25(4), 367-381. https:// doi.org/10.1016/0022-4405(87)90038-0

Gugus Tugas Percepatan Penanganan COVID-19. (2020). Peta Sebaran Kasus COVID-19 di Indonesia. Covid19.Go.Id. 
Haryanti, D., Ashom, K., \& Aeni, Q. (2019). Gambaran Perilaku Orang Tua Dalam Stimulasi Pada Anak Yang Mengalami Keterlambatan Perkembangan Usia 0-6 Tahun. Jurnal Keperawatan Jiwa, 6(2), 64. https://doi.org/10.26714/jkj.6.2.2018.64-70

Hasanah, A. U. (2019). Stimulasi Keterampilan Sosial untuk Anak Usia Dini. Fascho: Kajian $\begin{array}{llll}\text { Pendidikan Dan Sosial Kemasyarakatan, } & \text { 9(1), }\end{array}$ https://doi.org/10.24042/ajipaud.v1i2.3508

Jamaluddin, D., Ratnasih, T., Gunawan, H., \& Paujiah, E. (2020). Pembelajaran Daring Masa Pandemik Covid-19 Pada Calon Guru: Hambatan, Solusi dan Proyeksi. Karya Tulis Ilmiah UIN Sunan Gunung Djjati Bandung, 1-10.

Kandari, N., \& Ohorella, F. (2020). Penyuluhan Physical Distancing Pada Anak di Panti Asuhan Al Fakri. Jurnal Abdimas Kesehatan Perintis, 2(1), 37-41.

Karnawati, \& Mardhianto. (2020). Sekolah Minggu Masa Pandemi Covid 19 : Didaché:Journal of Christian Education, 1(1), 13-24. https:// doi.org/10.46445/djce.v1i1.291

Karo, R. K., Haenilah, E. Y., \& Fatmawati, N. (2019). Perkembangan Sosial Anak Melalui Permainan Modern Rama. Jurnal Pendidikan Anak PG-PAUD FKIP Universitas Lampung, 5(1).

Khusniyah, N. L. (2018). Peran Orang Tua sebagai Pembentuk Emosional Sosial Anak. Qawwam, 11(2), 87-101. https://doi.org/10.20414/qawwam.v12i1.782

Kilic, K. M., \& Aytar, F. A. G. (2017). The effect of social skills training on social skills in early childhood, the relationship between social skills and temperament. Journal: Education and Science, Egitim Ve Bilim, 42(191), 185-204. https://doi.org/10.15390/EB.2017.7162

Langeveld, J. H., Gundersen, K. K., \& Svartdal, F. (2012). Social Competence as a Mediating Factor in Reduction of Behavioral Problems. Scandinavian Journal of Educational Research, 56(4), 381-399. https:// doi.org/10.1080/00313831.2011.594614

Lestari, D. S. D. (2018). Social Skill Komunitas Motor CBR (JCRI). Prodi Psikologi Fakultas Psikologi Universitas Ahmad Dahlan Yogyakarta.

Lestari, P. (2018). Efektivitas Metode Bermain Peran dalam Mengembangkan Keterampilan Sosial Anak Usia 5-6 Tahun Taman Kanak-kanak Assalam 2 Sukarame Bandar Lampung. Universitas Islam Negeri Raden Intan Lampung. https:// doi.org/10.29406/jepaud.v6i1.1363

Lindberg, S. (2020). Impact of Isolation on Childhood Development. Verywell Family.

Lynch, S. A., \& Simpson, C. G. (2010). Social Skills: Laying the Foundation for Success. Dimensions of Early Childhood, 38(2), 3-12.

Mahanani, M. (2015). Hubungan perhatian orangtua dengan perkembangan sosial anak usia 4 -5 tahun di desa birit Kecamatan Wedi Kabupaten Klaten tahun 2015. Universitas Negeri Yogyakarta.

Mahmudi, A., Sulianto, J., \& Listyarini, I. (2020). Hubungan Perhatian Orang Tua Terhadap Hasil Belajar Kognitif Siswa. In Jurnal Pedagogi dan Pembelajaran (Vol. 3, Issue 1). https://doi.org/10.23887/jp2.v3i1.24435

Marinho, M. L., \& Casanova. (2017). Environmental influence on the development of social skills in children. Extensio: Revista Eletrônica De Extensão, 14(26), 2-11. https://doi.org/10.5007/1807-0221.2017v14n26p2

Mukarromah, T. (2019). Dampak Penggunaan Gadget Pada Perkembangan Sosial Anak Usia Dini Di Dusun Setia Bumi Kecamatan Seputih Banyak. Institut Agama Islam Negeri (IAIN) Metro.

Nandwijiwa, V., \& Aulia, P. (2020). Studi Deskriptif Peran Orang Tua terhadap Perkembangan Sosial Anak Usia Dini pada Masa Pandemi Covid-19. Jurnal Pendidikan Tambusai, 4(3), 3145-3151. https:/ / doi.org/10.29408/iga.v4i02.2520

Negoro, E. S., \& Lestari, S. (2019). Peran Orang Tua dalam Mengembangkan Sikap Prososial Pada Remaja Laki-laki. Universitas Muhammadiyah Surakarta. 
Nuraida, E., \& Milyartini, R. (2016). Meningkatkan Keterampilan Sosial Anak Usia Dini Melalui Kegiatan Bermain Angklung ( Penelitian Tindakan Kelas di TK Laboratorium Percontohan Universitas Pendidikan Indonesia ). Swara, 4(2), 1-14.

Pahenra, Salwiah, \& Taslim, N. R. (2018). Deskripsi Pola Asuh Orang tua yang Bekerja Pada Anak Usia Dini di TK Tunas Makarti Kota Kendari. Jurnal Smart PAUD, 1(2), 176-182. https://doi.org/10.36709/jspaud.v1i2.4730

Permata, A., \& Bhakti, Y. B. (2020). Keefektifan Virtual Class dengan Google Classroom dalam Pembelajaran Fisika Dimasa Pandemi Covid-19. JIPFRI (Jurnal Inovasi Pendidikan Fisika Dan Riset Ilmiah), 4(1), 27-33. https://doi.org/10.30599/jipfri.v4i1.669

Prantoro, G. (2015). Pengaruh Penggunaan Permainan Tradisional Bakiak dan Engklek Terhadap Keterampilan Anak Usia Dini. E-Jurnal Skripsi Prodi Teknologi Pendidikan, 4(3), 1-10.

Pratiwi, M. R., Mukaromah, \& Herdiningsih, W. (2018). Peran Pengawasan Orang tua Pada Anak Pengguna Media Sosial. Jurnal Penelitian Pers Dan Komunikasi Pembangunan, 22(1), 35-37. https:// doi.org/10.46426/jp2kp.v22i1.73

Prodjo, W. A. (2020). Saat Covid-19, Dukungan Psikososial Anak Penting Diberikan. Kompas.Com.

Pujiningtyas, M. (2018). Strategi Guru Dalam Pengembangan Sikap Sosial Anak Di Taman Kanak-Kanak Islam Tarbiyatul Banin Ii Kota Salatiga. Institut Agama Islam Negeri (IAIN) Salatiga.

Rachman, S. P. D., \& Cahyani, I. (2019a). Perkembangan Keterampilan Sosial Anak Usia Dini. Jurnal Pendidikan Raudhatul Athfal (JAPRA), 2(1), 52-65. https:// doi.org/10.15575/japra.v2i1.5312

Rachman, S. P. D., \& Cahyani, I. (2019b). Perkembangan Keterampilan Sosial Anak Usia Dini. (JAPRA) Jurnal Pendidikan Raudhatul Athfal (JAPRA), 2(1), 52-65. https:// doi.org/10.15575/japra.v2i1.5312

Rakhmawati, I. (2015). Peran Keluarga dalam Pengasuhan Anak. Jurnal Bimbingan Konseling Islam, 6(1), 1-18. https:// doi.org/10.21043/kr.v6i1.1037

Rubin, K. H., Bukowski, W. M., Parker, J. G., \& Bowker, J. C. (2008). Peer Interactions, Relationships, and Groups. Developmental Psychology: An Advanced Course, 1-82. https:// doi.org/10.1002/9780470147658.chpsy0310

Saputri, D. I., Siswanto, J., \& Sukamto. (2019). Pengaruh Perhatian Orang Tua dan Motivasi Berprestasi terhadap Prestasi Belajar Fisika. Jurnal Pedagogi Dan Pembelajaran, 2(3), 369-376. https://doi.org/10.23887/jp2.v2i3.19285

Sarnelle, K. Y. (2018). Teacher perspectives on social thinking. Rowan University.

Setiawan, H. Y. (2017). Permainan Kooperatif Dalam Mengembangkan Keterampilan Sosial Anak Usia Dini. Jurnal AUDI, 1(1), 32-37.

Sloane, A., \& Seale. (2009). Research Design: Qualitative, Quantitative, and Mixed Methods Approaches. Canadian Journal of University Continuing Education, 35(2), 223-223. https:// doi.org/10.31004/obsesi.v5i1.577

Stagnitti, K. (2004). Understanding play: The implications for play assessment. Australian Occupational Therapy Journal, 51(1), 3-12. https://doi.org/10.1046/j.14401630.2003.00387.x

Sukatin, Qomariyyah, Horin, Y., Afrilianti, A., Alivia, \& Bella, R. (2020). Analisis Psikologi Perkembangan Sosial Emosional Anak Usia Dini. Jurnal Pendidikan Anak Bunayya, 6(2), 156-171. https:// doi.org/10.14421/jga.2020.52-05

Sunardi, J., \& Kriswanto, E. S. (2020). Perilaku hidup bersih dan sehat mahasiswa pendidikan olahraga Universitas Negeri Yogyakarta saat pandemi Covid-19 Clean and healthy life behavior of Yogyakarta State University sports education students during the Covid19 pandemic. Jurnal Pendidikan Jasmani Indonesia, 16(2), 156-167. https:// doi.org/https:// doi.org/10.21831/jpji.v16i2.35082 
DOI: 10.31004 /obsesi.v6i1.959

Suud, F. M. (2017). Pengembangan Keterampilan Sosial Anak Usia Dini (Analisis Psikologi Pendidikan Islam). AL-MANAR: Jurnal Komunikasi Dan Pendidikan Islam, 6(2), 227253. https:// doi.org/https://doi.org/10.36668/jal.v6i2.11

Syafrida, R. (2014). Regulasi Diri dan Intensitas Penggunaan Smartphone Terhadap Keterampilan Sosial. Jurnal Pendidikan Anak Usia Dini, 8(2), 375-384. https://doi.org/https://doi.org/10.21009/JPUD.082

Tahmores, A. H. (2011). Role of play in social skills and intelligence of children. Procedia Social and Behavioral Sciences, 30, 2272-2279. https://doi.org/10.1016/j.sbspro.2011.10.444

Takahashi, Y., Okada, K., Hoshino, T., \& Anme, T. (2015). Developmental Trajectories of Social Skills during Early Childhood and Links to Parenting Practices in a Japanese Sample. Polos One, 1-14. https://doi.org/10.1371/journal.pone.0135357

Umayah. (2017). Perkembangan Sosial Pada Anak Usia Dini. As-Sibyan Jurnal Pendidikan Anak Usia Dini, 2(1), 85-96.

UNICEF. (2020). Kiat Pengasuhan di Tengah Wabah Virus Corona (COVID-19). Unicef.Org.

Wahyuni, F., \& Azizah, S. M. (2020). Bermain dan Belajar pada Anak Usia Dini. Al-Adabiya: Jurnal Kebudayaan Dan Keagamaan, 15(1), 159-176. https://doi.org/10.37680/adabiya.v15i01.257

Wang, G., Zhang, Y., Zhao, J., Zhang, J., \& Jiang, F. (2020). Mitigate the effects of home confinement on children during the COVID-19 outbreak. In The Lancet (Vol. 395, Issue 10228, pp. 945-947). Lancet Publishing Group. https://doi.org/10.1016/S01406736(20)30547-X

Wardhanii, I. K. (2020). Stimulasi Perkembangan Sosial Anak Selama di Rumah. PUSPENSOS (Pusat Penyuluh Sosial).

Wiresti, R. D. (2020). Analisis Dampak Work From Home pada Anak Usia Dini di Masa Pandemi Covid-19. Jurnal Obsesi: Jurnal Pendidikan Anak Usia Dini, 5(1), 641. https://doi.org/10.31004/obsesi.v5i1.563

Wulandari, D. P. Y. (2020). Menjadi " Teman " bagi Anak di Masa Pandemi Anak dan Teman. Universitas Airlangga.

Wulandari, H., \& Purwanta, E. (2020). Pencapaian Perkembangan Anak Usia Dini di Taman Kanak-kanak selama Pembelajaran Daring di Masa Pandemi Covid-19. Jurnal Obsesi : Jurnal Pendidikan Anak Usia Dini, 5(1), 452. https:// doi.org/10.31004/obsesi.v5i1.626

Zhao, M., Wang, M., Zhang, J., Ye, J., Xu, Y., Wang, Z., Ye, D., Liu, J., \& Wan, J. (2020). Advances in the relationship between coronavirus infection and cardiovascular diseases. Biomedicine and Pharmacotherapy, 127(May), 1-15. https://doi.org/10.1016/j.biopha.2020.110230

Zulfitri. (2017). Pengaruh Pemberian Penguatan terhadap Perkembangan Moral Anak di Kelompok b3 TK Negeri Pembina Palu. Jurnal Pendidikan PAID, 4(2), 1-11. https://doi.org/10.31849/paudlectura.v1i2.1173 